\title{
"HERE IS THE HOUSE": A reading of the house(s) in The bluest eye, by Toni Morrison
}

\author{
Eliza de Souza Silva Araújo \\ (University of Massachussetts - Amherst/UFPB) \\ https://orcid.org/0000-0002-5324-3888 \\ Danielle de Luna e Silva \\ (UFPB) \\ https://orcid.org/0000-0001-6906-4246
}

\section{ABSTRACT}

In the present article we propose a reading of space in The bluest eye, by Toni Morrison, as a motif for plot and character development. The narrative takes place in Lorraine, Ohio, also hometown to Morrison. Other biographical elements appear in the narrative, the spatial being of utmost importance to this study. We explore the novel's houses as spatial elements that add to characters' subjectivities and embed the underlying theme of class. The narrative, which tells not only the story of Pecola, the protagonist, but gives us a detailed account of the lives of her mother, father, host family and community, starts with a simple description of a house as a place where a family lives and where everything comes together in harmony. This is done through the presentation of a primer which depicts language used in Dick and Jane books, texts historically used to initiate kids in reading. Such reference also implicates the representation of a perfect white suburban family where everyone gets along. Houses, furniture, backyards and other home-related elements foreshadow the unfortunate events to unravel in Pecola's life along the novel. In terms of their significance in a broader perspective, we grasp that houses are in the novel also to set and depict the families' background and current conditions in terms of class. Not only do houses help reinforce character traits, they stand as a social criticism to the economic conditions of blacks, also determined by whether their skin is darker or has a lighter shade.

KEY WORDS: Toni Morrison. Afro-American Literature. Social status. 


\section{“AQUI ESTÁ A CASA": Uma leitura da(s) casa(s) em The bluest eye, de Toni Morrison}

\section{RESUMO}

No presente artigo, propomos uma leitura do espaço em The bluest eye, de Toni Morrison, como um mote para o desenvolvimento das personagens. A narrativa se desenrola em Lorraine, Ohio, também cidade onde Morrison nasceu. Outros elementos biográficos aparecem na narrativa, o espaço sendo o de maior importância nesse estudo. Exploramos as casas do romance que adicionam à subjetividade das personagens e estão implicadas no tema de classe. A narrativa, que nos conta a história de Pecola, a protagonista, mas também nos dá um apanhado detalhado das vidas de sua mãe, pai, família acolhedora e comunidade, começa com uma simples descrição de uma casa como o lugar em que uma família vive e tudo se encontra em harmonia. Isso é feito através da apresentação de um primer que apresenta linguagem usada nos livros de Dick and Jane, textos historicamente usados para iniciar crianças na leitura. Tal referência também implica a representação de uma família branca e suburbana perfeita, na qual todos se entendem. Casas, mobília, quintais e outros elementos ligados à moradia prenunciam os eventos trágicos prestes a se desenrolar na vida de Pecola ao longo da narrativa. Em termos de sua significância numa perspectiva mais abrangente, entendemos que as casas estão no romance para determinar as origens sociais das famílias e suas condições presentes em termos de classe. Não só as casas reforçam características das personagens, elas também posicionam uma crítica social à condição financeira da população negra, também determinada pelo tom mais escuro ou mais claro de sua pele.

PALAVRAS-CHAVE: Toni Morrison. Literatura Afro Americana. Lugar social. 


\section{Introduction}

for Morrison as an African American writer home is in language, in survival through language, in a re-articulation of an imposed language in order to survive whole.

ROLAND WALTER, “Out of in-betweenness: reading Toni Morrison's (double) writing".

I am a black writer struggling with and through language that can powerfully evoke and enforce hidden signs of racial superiority, cultural hegemony, and dismissive "othering" of people and language which are by no means marginal or already and completely known and knowable in my work. My vulnerability would lie in romanticizing blackness rather than demonizing it; vilifying whiteness rather than reifying it.

TONI MORRISON, "Preface".

The bluest eye was the first novel written by Nobel Prize-winning author Toni Morrison and it was published in 1970. In the afterword to the 1994 edition, she states how the idea of the plot came about: as a child, Morrison once attended school with a black girl who confessed to her that she wished she could have blue eyes. In the author's words: "We had just started elementary school. She said she wanted blue eyes. I looked around to picture her with them and was violently repelled by what I imagined she would look like if she had her wish" (MORISSON, 1994, p. 209).

Morrison furthermore expresses that she was angry at her classmate for having that wish, but also shares how the event helped her inquire and challenge her own notions of beauty. She could realize that such a statement made by a child was in a way, telling of a culture that produced ideals of beauty that did not contemplate the complexion or body features of a girl with really dark skin. She also felt that the wish had, embedded in itself, self-loathing. She then questioned where such strong emotions came from and how they could threaten the mind and even the sanity of a young black girl. 
It is interesting to see how beauty is a theme in the narrative, often revolving around female characters, after all, society demands that women be beautiful and stay beautiful as they age, and does not require the same from men. In another reflection in the "Afterword", Morrison points out that "[b]eauty was not simply something to behold; it was something one could $d o$ " (idem). This statement may imply that beauty is the driving force of the person who possesses it, but at the same time, it implies that beauty legitimizes a person's actions. Beauty then, does not simply make one do things, it allows one to do things and have power in the world outside of oneself. The pursuit of beauty drives Pecola, a child, but also adult women like China, Poland, Maginot Line and Pauline. Beauty, in a way, orients their everyday life and makes an impact even in their closest relationships.

In her critical essays, Morrison also tackles the topic of beauty. In "Behind the making of The Black Book", for instance, she points out that the slogan Black is beautiful does not help blacks because it shifts their attention to beauty as if it were a value, and more important than race itself. In "Rediscovering Black History" she adds that such a slogan even confuses people about what their worth is.

Because beauty is such a complex and nuanced life element, it is expected that it would govern the thoughts of a young child who seeks acceptance, but beauty is in a way so overrated in American culture, that adults also get distracted by it and depend on it to navigate this world. Beauty and class are also intertwined in the novel, and that emphasizes the idea Morrison articulates in the afterword: beauty in the novel is what one can $d o$. The idea of beauty then, is magnified in this novel as it goes from the individuals to the outside sphere of houses, neighborhoods and surroundings, where beauty also defines status. White people's houses and costumes are described beautifully, with adjectives of praise, whilst black people's homes are often described in a more negative way, and the people who live in them are more exposed in their contradictions as being personally chaotic as well. In the present article, we aim to discuss how the space is presented in the novel as a motif for plot and character development. Space and the beauty of space are reflected on the people in the communities described and through space we gather the underlying theme of class in the novel. 


\section{Autobiographical elements in The bluest eye: a} sense of home

Armindo da Costa Gameiro (2012) understands that our current times favor the blooming of more and more narratives of the self. The demand for that type of text aims at unraveling the mysteries of the self and one's place in the world. Nonetheless, Gameiro adds that there are problems involving the first person within fiction. According to him, it may raise questions as to whether the text presents a fictional self or an altogether illusion. All of these matters link to the complexities of self, making it a challenge to believe in what one writes or not, once the self (the written and the performing layers of someone) brings about the idea of a whole and not an easily definable or limitable one.

Although Morrison's narrative is not explicitly a narrative of the self, we consider it of utmost importance to value the fact that the idea for writing the novel came from a personal life experience that resonated with the author throughout her childhood and teenage years, until she became an adult and began working on the story. Morrison's personal experience was the genesis of the story and its main character, Pecola Breedlove. The novelist calls the book "the public exposure of a private confidence" (1994, p. 121), therefore admitting the fact that she went through the event that originated the motif, leading her to later write about it fictionally. The writer also understands that her writing voice expresses the struggles of black people as a group: "The publication (as opposed to the writing) involved the exposure; the writing was the disclosure of secrets, secrets 'we' shared and those withheld from us by ourselves and by the world outside the community" (idem). We believe then, that this narrative on some level involved the writing of the self as a strategy to reach the desired outcome.

In "Intimate things in place: a conversation with Toni Morrison", Robert Septo notes that a "sense of place" (SEPTO, 1994, p. 10) is often perceived in Morrison's novels. The novelist later emphasizes that she feels places in a number of ways, and this connection between details in places and the identity only the thorough description of such places is able to bring about in her novels. She adds: "In the first book, I was clearly pulling straight out of what autobiographical information I had. I didn't create that town. It's clearer to me now in my memory of it than when I lived there" (idem). Morrison then, goes back to the fact 
that autobiographical elements inform her fiction very much in the way in which feeling is being communicated in the narrative through the investment on space.

In "Unspeakable things unspoken: The Afro-American presence in American Literature", Morrison gives us more input on the creative process of writing The bluest eye. She poses that her first sentence in the book, "Quiet as it's kept, there were no marigolds in the fall of 1941." (1994, p. 5), was meant to be simple and loaded with meaning. She intended for it to sound like a child listening to adults' conversations. On presenting this atmosphere for the beginning of the novel, the author restates that her idea was to deal with secrets, things that are not commonly discussed or shared. She tells us that author and reader, at that moment, were sharing that space of telling and listening to a secret and as an author, she thought out the process of using this narrative introduction as a means for setting the tone of the children's presence in the plot as well as making the reader aware of their importance in the story.

Point of view was also something carefully chosen: Morrison wanted to use the perspective of the violated young females to carry out the telling of events. She breaks a silence in the beginning, tells secrets and gives projection to matters that were not being discussed in the black community at that time: the abuse of young females within their broken families. Pecola, in that context, is unable to see beauty in herself for she is surrounded by ugliness, the same one her family wore according to the narrative voice. The only moment when she takes a proper inner look at herself and sees a whole complex human, with various features and layers to self - other than beauty -, is when she loses her mind and hallucinates. At this point in the novel, the fragmentation of the self, allows her to look at herself in a different light, which she was unable to accomplish before.

Eurídice Figueiredo (2013) recognizes that autobiographical genres have been growing and changing, especially after the 1980s. She considers the novel to be an "impure genre" (p. 13), which allows various for$\mathrm{ms}$ of discourse to enter narrative. She makes an important point, useful for us in our analysis of Morrison's book: often times, books that are not explicitly autobiographical or autoficcional, may include biographemes ${ }^{1}$.

1 Our translation. Biographemes (biografemas, in Portuguese), are bits and pieces of the author's life that may be present in the text, a piece which does not necessarily promise pure truth. 
We believe that the presence of biographemes in The bluest eye adds to the intimate tone between narrator and reader which is developed and deepened throughout the narrative. Morrison's school experience with the girl who wanted blue eyes, the main setting of the novel being her hometown Lorraine, Ohio, her thorough description of streets, houses and any other area where characters transit certainly does bring an even greater depth to the level of intimacy evoked in the writing and the creation of the appropriate environment for the sharing of secrets. Narrator and audience (readers) then, share the innermost atrocities of black lives, in a language that is not dubious or apologetic, for it is aimed at denouncing racism and making people uncomfortable about feelings they might have, hide and never question: related to blackness or to the experience of being black in the United States. In this sense, not only is the narrator telling us (readers) a secret, but in a way, so is Morrison (the writer, woman) revealing herself to us.

\section{A reading of the meanings in The bluest eye}

Roland Walter (2003) recognizes that Morrison's work in her novels is characterized by a recreation of the past and present experiences of blacks, and also by references to the Afro-diasporic experience and therefore, to a sense of home. That in itself, would be enough to justify the author's investment in space in The bluest eye, which is a book that questions the ideals of homes as well as those of the perfect families, while it walks us through an intricate perception of space as an element that is constructive of characters as much as characters' personal history is. Walter understands that

By problematizing specific aspects of the past and their impact on the present, Morrison foregrounds the question of African American identity as a continuous journey between homelessness and "home", within, in between, and across the borders of a racialized society (...) (p. 98).

The journey that Walter describes in this excerpt is exactly the one that Pecola, the protagonist in The bluest eye, undergoes in the plot. She is a girl who has been living in a dysfunctional family for a while. Her father: her rapist. Her mother: her harshest critic who tells her she is not beautiful. Her whole existence in the community is reinforced by her nature of an outsider, notwithstanding the fact that she lives in a black community and is a black girl herself. In being put outdoors in a community 
where people struggle, her condition is magnified by other members of the "margin", resulting in her inability to fit in with her own peers, the people who share the same space in the city of Lorraine.

She used to live in a house that was once a store, which her family shared with three prostitutes living in the upper floor. She is witness to her father's violence towards her mother, a victim of his abuse and rape and sees the further dismantling of the family, her house set on fire and her father being sent to prison. Her journey then is marked by a sense of homelessness, a lack of acceptance even within her nuclear family which sets her as an unprotected child, someone who needs affection, love and acceptance because she did not experience these things in her own family.

Pecola is thrust into the "outdoors" by the tragedy involving her family and that is a situation which brings about a sense of humiliation - for she is homeless and unable to live in her family's house, which has been destroyed and more seriously she is unable to be taken care of, due to the breaking of her family.

The narrator Claudia MacTeer tells us at the beginning that Pecola's father, Cholly Breedlove, "that old Dog Breedlove had burned up his house, gone upside his wife's head, and everybody, as a result, was outdoors" (MORRISON, 1994, pp. 16-17). The narrator's perception of the outdoors is rather negative and full of fear. That perception drives the sisters' look at Pecola. They see her as a child, incapable of defending herself from all the injustices she has been a victim of, and to make matters worse, she is a child who has been put outdoors by her own father, who was supposed to protect her.

Outdoors, we knew, was the real terror of life. The threat of being outdoors surfaced frequently in those days. Every possibility of excess was curtailed with it. If somebody ate too much, he could end up outdoors. If somebody used too much coal, he could end up outdoors. People could gamble themselves outdoors, drink themselves outdoors. Sometimes mothers put their sons outdoors, and when that happened, regardless of what the son had done, all sympathy was with him. He was outdoors, and his own flesh had done it. (...) Cholly Breedlove, then, a renting black, having put his family outdoors, had catapulted himself beyond the reaches of human consideration. (ibidem, pp. 1718).

As a result of being put outdoors, a sense of home was lost. We may ultimately argue that Pecola felt homeless all along. Her quiet nature 
and apparent sadness come from that lack of attachment to her family and more importantly, the lack of affection. She is not reassured in who she is, she gets no recognition or love for being herself and existing in the world.

Another interesting narrative choice is that the book opens with a primer in which we see simplistic chunks taken from or imitating a Dick and Jane ${ }^{2}$ book, which Timothy B. Powell (1990) calls a white text. According to Powell, Morrison makes this choice because she wants to call the reader's attention to the fact that Afro-American writers were often forced to use the "Master's language" (p. 749) to address to readers in their texts. The reference to Dick and Jane then, comes as a symbol to the ethnocentric culture and the white values of American families. Powell further explains: "The all-too-familiar lines of the Dick-and-Jane primer also serve as an important contrast, pointing out an essential difference between the cold, clear logic of the white text and the often irrational pain of the black text which is to follow" (idem). The Dick and Jane lines, as well as the Shirley Temple mug, for Powell, are symbols of the white logos, which depicts how society poses beauty standards before Pecola's eyes. These are the models to which she compares herself. The description of the model-house, which opens the narrative, starts as it follows:

Here is the house. It is green and white. It has a red door. It is very pretty. Here is the family. Mother, Father, Dick, and Jane live in the green-and-white house. They are very happy. See Jane. She has a red dress. She wants to play. Who will play with Jane? See the cat. It goes meow-meow. Come and play. Come and play with Jane. The kitten will not play. See Mother. Mother is very nice. Mother, will you play with Jane? Mother laughs. Laugh, Mother, laugh. See Father. He is big and strong. Father, will you play with Jane? Father is smiling. Smile, Father, smile. See the dog. Bowwow goes the dog. Do you want to play with Jane? See the dog run. Run, dog, run. Look, look. Here comes a friend. The friend will play with Jane. They will play a good game. Play, Jane, play (MORRISON, 1994, p. 3).

2 Dick and Jane books are anonymous readers that were aimed at teaching young children to read through language patterns, making constant use of repetition, sight words and simple images. The language in the books is presented in chunks rather than in a smooth storyline. The characters in these books are white children who are well-off and live in a suburban area. Although versions with black children have come about, the standard and most publicized versions are the ones with Dick and Jane, who represent the beautiful, peaceful and role-model children of white America. 
The house in this depiction is seen in bright colors and happy childhood scenes determine the playful tone of the everyday life of the family. The family is composed of the Mother, Father, sister, brother, cat and dog. Jane, the girl-child, has the attention she seeks in this environment, as everyone in the scene looks at her and smiles or laughs. All the described action revolves around Jane and her willingness to play. They look at her, notice her, smile at her. We do not know the names of the Mother and Father, but their capitalized titles are a sign of their existence in relation to Jane. The girl in the scene is living a happy, well-adjusted childhood, where she seems to have no worries. She is learning through play and surrounded by healthy relationships to the Mother, Father and brother. The scene is described in such perfection, that the irony in it is undeniable. A utopian house, family life and childhood are depicted in simplistic language, which also determines how easy, natural and appealing this type of model-life is. The excerpt however is deconstructed in order for the narrative of Pecola's life to begin.

The same excerpt is repeated right after it ends and this time, punctuation disappears and the only capital letter we see is the $\mathrm{H}$ in Here, at the beginning of the first sentence. Later, the piece reappears once more, without punctuation, capitals or spaces. The way the words tend to go faster and the breathless sensation of reading a paragraph without pausing bring about tension, anxiety and an uneasiness that help build for the story that is to come: the story of Pecola. Parts of this Dick and Jane section are later repeated in the opening of new chapters, indicating what topic will be dealt with. All the important and iconic elements in it, come at some point in the narrative: we learn about the mother, the father, the brother, a cat, the house. The opening lines of the chapters that follow are always fragments of the aforementioned excerpt, all in capitals, without any spaces or punctuation, which enforces the tense atmosphere throughout the narrative.

When Pecola's house is introduced, it becomes clear how far it is from that expectation of a happy and harmonious house from the primer, ironically idealized by us readers. Here is her actual house:

There is an abandoned store on the southeast corner of Broadway and Thirty-fifth Street in Lorain, Ohio. It does not recede into its background of leaden sky, nor harmonize with the gray frame houses and black telephone poles around it. Rather, it foists itself on the eye of the passerby in a manner that is both irritating and melancholy. 
(...) So fluid has the population in that area been, that probably no one remembers longer, longer ago, before the time of the gypsies and the time of the teen-agers when the Breedloves lived there, nestled together in the storefront. Festering together in the debris of a realtor's whim (MORRISON, 1994, pp. 33-34).

The very first contrasting aspect of the house of Dick and Jane and the Breedloves' is the colors. Here is a description of a house that was once an abandoned store and its color does not match the grey sky or the telephone poles that surround it. It is an aggressive image for the passerby, and it is located in a crowded area where great deals of people come and go. The narrator later describes how the family members who came to occupy that space would transit as if they were nobodies: "They slipped in and out of the box of peeling gray, making no stir in the neighborhood, no sound in the labor force, and no wave in the mayor's office" (p. 34). Their existence is described as fragmented, broken into pieces, silent.

Inside the house, those perceptions can be reinforced: we see a living room, a bedroom, a kitchen. The living room has two sofas, a piano (that no one plays) and a dusty Christmas tree, while the only bedroom has two iron beds for the kids and a double bed for the adults, a coal stove in the middle of it and a cardboard wardrobe. The house bears no bathroom. The sofa is one of the most described elements of the living room. It was delivered with a rip and could not be returned. They had to pay monthly for the sofa anyway and cope with the lack of joy of keeping a dysfunctional object. It stank and was made of cheap material that deteriorated fast. It was "a hated piece of furniture" (p. 37) inside a house that was not loved either.

What are then the meanings underlying these descriptions? Everything described in the Dick and Jane house and the outside area harmonize with the happiness and playfulness of the girl child Jane. She is a happy girl, well-behaved and mannered, full of energy and joy. When we see Pecola's house, though, all of the description of the space plays into her nature as a character. The grey color and her quiet ways, the piano that plays no music and her sadness, the collective bedroom and her traumatic relationship with both parents. She is exposed to a lot of harm and abuse inside her own house, rather than protected in it.

Barbara Christian (1985) sees that in Morrison's novels communities are of great importance, as well as blood relations and Nature, therefore, space is foregrounded in the narration. The scholar also understands the 
houses in The bluest eye as relating completely to character traits and subjectivities. She poses that "[f]rom the ugly storefront of the Breedloves to the standardized house of the Dick and Jane primer, the houses in this novel reflect the worth of their inhabitants according to the norms of the society and emphasize the destructiveness of a hierarchical order" (p. 52). The way houses are, and the way they are seen by others has a potential to destroy the lives of those who are already marginalized. It means to say the way the status quo works in this society can and most likely will continue this cycle of empowering one race over another and one class over another.

Claudia MacTeer, right in the beginning of the narration of the arrival of Pecola at her house, shows us that she knows their class determines their place in society: "Being a minority in both caste and class, we moved about anyway on the hem of life, struggling to consolidate our weakness and hang on, or to creep singly up into the major folds of the garment" (MORRISON, 1994, p. 17). Claudia does not see an easy way out of their situation. They could either resign and accept they are weak, or they could try and change their garments, their appearance, the way they present themselves to the others. However, that change of garment could only be done singly, apart from others. In terms of class, she could not see the rise of her community as a whole. It is also important to observe the use of the word caste in her statement. Although castes are rigid systems of grouping people together into different social divisions and it is not a system employed in the United States (as it is in India, for example), this word is also chosen by Christian when tackling the question of women: white and black.

In her analysis of Morrison's novels, Christian (1985) articulates an understanding of the relation gender-class as one that is deeply rooted in history and important in outlining the past in the representation of black women in literature. She poses that "(...) women were relegated to an underclass in America by virtue of their race (...) within that separate caste, a standard of woman was designed in terms of a class definition" (pp. 71-72). The ideal, respectable woman in this context is beautiful, pure, a mother, white and upper middle-class. It is a concept that Christian takes as "not only sexist and racist, it is also classist" (p. 72). One of the most important reasons why black women were not admitted in this group had to do with class, but also with the fact that they were not considered beautiful. Christian observes that 
The Breedloves despise themselves because they believe in their unworthiness, which is translated into ugliness for the women of that family. Associated with their condition is funk, violence, ugliness, and poverty, symbolized in the storefront house. In contrast, Pecola's mother, Pauline, works as a domestic in a beautiful house that is a reflection of the ideal woman. (...) In a pivotal section of the novel, Pauline expels her "ugly", "poor" daughter Pecola from this house because she drops a hot pan of blueberry pie and dirties the floor ( $\mathrm{p}$. 74).

This episode in the novel happens after Frieda and Claudia decide to walk to the house where Pauline (Pecola's mother) works because they have been told Pecola was there. An interesting nuance can be observed as they start walking towards the house: we have a thorough description of how their surroundings are changing and the public places are becoming clean, the colors of houses are becoming brighter as they move from their poor neighborhood and into a wealthy area of the town.

We walked down tree-lined streets of soft gray houses looked more sturdy, their paint was newer, porch posts straighter, yards deeper. (...) The lakefront houses were the loveliest. Garden furniture, ornaments, windows like shinny eyeglasses, and no sign of life. (...) The sky was always blue.

We reached Lake Shore Park, a city park laid out with rosebuds, fountains, bowling greens picnic tables. It was empty now, but sweetly expectant of clean, white, well-behaved children and parents who would play there above the lake in summer before half-running, half-stumbling down the slope to the welcoming water (MORRISON, 1994, p. 105).

The candid and positive description of the environment in the white neighborhood shows a harsh contrast to the description of the surroundings of Pecola's house. In the wealthy neighborhood people have infrastructure, clean places, flowers, a view from the elegantly decorated porches of their houses. They have backyards that are green and lead to the lake. They are in contact with nature in its cleanest form. At one point in the description of the park, the narrator lets us know that black people were not allowed in there. The girls walk a path where they are confronted by the privilege of whites and are amused by what is on the other side, until they meet Pecola, who is playing in the outside yard by herself. Mrs. Breedlove shows up and invites the girls in. That's when they meet the 
child in the house, who calls Mrs. Breedlove "Polly" while Pecola has to call her Mrs. Breedlove.

The conflict in Pecola's interaction with her mom in her workplace, the perfect environment she talks so much about, culminates in her being expelled from the house. Before that, she is humiliated in front of Claudia and Frieda, for her mother knocks her for dropping the pan on the floor she had cleaned. Pecola has to leave the house, humiliated by the accident she had just caused and by the fact her mom never tells the girl child who she works for, who they were. That is not the only moment when Pecola is expelled from a house.

The same had happened when she went to a classmate's house before, in a section where he coaxes her into entering his house to see kittens. Junior, Geraldine's son, is used to feeling superior to others, especially to other black kids, for having lighter skin. He lives by the school and one day, sees Pecola pass by. He finally invites her in. His house is big, beautiful, decorated with table centers and rugs. There are also inside plants and a lot of beautiful features to observe, which he does not let Pecola do. He hurries her only to throw a black cat in her face. She gets clawed and wants to go, but he does not let her. Junior later grabbed the blue-eyed cat by his hind legs and spun it. When Pecola tries to stop him, he lets go of it and it hits the window and falls down, apparently dead. Geraldine comes in at this point and Junior accuses Pecola of killing their pet. By looking at Pecola, she remembers all black girls she has come across and how much hatred she has toward them. That is when she shuts Pecola out and insults her by calling her a "nasty little black bitch" (MORRISON, 1994, p. 92). She has to go with a ripped dress out in the cold and snowy weather of March.

If we look at these two events and consider a broader perspective, we can grasp that Pecola did not fit in her home which is no longer there, and was not welcome in two other homes, in situations where she sought attention and affection.

At the beginning of the novel, she is admitted into the MacTeer's house. There, the girls realize she is in need of friends and embrace her presence. Their mother on the other hand, is constantly complaining about the guest's presence and repeatedly expresses how disappointed she is about the fact that the girl drinks too much milk. The house where Pecola is the safest, is still not the most affectionate environment.

In an interview with Betty Jean Parker (1979), Morrison explains 
that she intended to write about a girl who was a victim, but she adds that " $t \mathrm{t}]$ he novel is about a passive kind of person and the people around her who create the kind of situation that she is in" (p. 61). The people around Pecola are very responsible for her condition and her lack of a sense of home. They are unable to love her enough and to embrace who she really is in order to provide that safe haven for her, like the one Jane (from the Dick and Jane primer) finds in her home, within her own family.

For Christian (1985), in Morrison's novels, "[s]etting (...), is organic to the characters' view of themselves. And a change in place drastically alters traditional values that give their life coherence" (p. 48). Drawing from such statement, we may argue that Pecola's view of herself is also negative because of the ugliness of her surroundings, and the inability to be inserted and accepted into a beautiful, clean and organized place that is different than those where she dwells: dirty places that are worn-out, sad or unwelcoming. Although in the book, we can see the questioning of beauty standards and the claim that beauty is not restricted to one race or skin color, Pecola is affected by these very standards, where what is valuable, clean and successful is inherently white.

Pauline's way to escape this adversity is to work in a white neighborhood, in a perfect house, where she can project her perfect life and imagine she belongs in there. Pecola, as a child, has no system, no strategy to escape her view of herself. The ugliness of the places and the people around her cause her self-loathing; the same Morrison says she understood the girl who wanted blue eyes in her school had. Pecola drowns in selfhatred because she cannot fight the outside forces that standardize beauty and she receives no love strong enough that she can draw strength from. Claudia sees beauty in her, although she realizes that Pecola herself will never see it: "she would never know her beauty. She would see only what there was to see: the eyes of other people" (MORRISON, 1994, pp. 46-47).

Ozíris Borges Filho (2007) states that space exists in narratives, to help us make sociological, philosophical and structural inferences. Space in literature is dynamic and it is a means for the narrator to create specific effects. Borges Filho also considers space to be a projection of the psyche of characters. He supports theories by Bachelard and Fernando Seixas in affirming that. He goes on to say that a change of spaces tends to influence a change in characters' actions. Borges Filho also articulates that in the introduction to a narrative, we have a presentation of what is about to take place. At this point, we also get to know the "first space" (p. 43), which is 
key to the interpretation of the text. Often times, we may need to contrast this first space and the one at the end of the narrative in order to observe what effects that change of space provokes, or how it changes and what effects can be observed.

In The bluest eye, the space that opens the narrative is the house of Dick and Jane, which is gradually deconstructed throughout the narration. We are introduced to several spaces, which generate different effects on Pecola. Such spaces cause a change in her inner herself. She is affected by the time at the house of the MacTeers, by her school interactions, her return to her own home, her visit to her mother's workplace, and so forth. In clashing with the non-acceptance she encounters along the way, Pecola reinforces her understanding that she must hate herself and later comes to terms with her eccentric desire to have blue eyes by acquiring them, while also hallucinating.

At the end of the text, we are unsure of where Pecola is, but the last scene Claudia paints for the reader is this: "And now I see her searching the garbage - for what? The thing we assassinated? I talk about how I did not plant the seeds too deeply, how it was the fault of the earth the land, our town" (MORRISON, 1994, p. 206). The madness, the only way she gets to see through herself and sees a best friend in herself, lands her in that place, searching the garbage, for something unknown to Claudia. This excerpt is also very complex in its suggestions about space. The reason why the Marigolds did not flourish and in a similar way, why Pecola did not flourish in becoming the woman she was meant to be, is the earth's fault. As well as it is the land's fault - because racism and cruelty directed to dark-skinned girls rendered them unable to flourish. It is also the town's fault, because although Pecola was surrounded by people - some of whom loved her -, they were unable to help her love herself.

Samantha Alongi (2009) observes:

It is Pecola's impossible desire for blue eyes, as a result of the cruelty she tolerates throughout this novel, which leads her to seek aid from Soaphead Church. If this scene had occurred anywhere else within the text, it would have altered readers' ability to realize how desperate Pecola truly was. The empathy audiences experience on Pecola's behalf comes to a climax upon the realization that Pecola has sought out the help of a known pedophile in order to satisfy her desire (p. 102). 
Certainly, Soaphead Church is to blame for the shape in which we see Pecola at the end of the novel. However, Claudia is open to taking on part of that responsibility as well and sharing it with her community. It was not only Pecola's nuclear family who failed to love her and to help her out of her obsession for blue eyes, a desperate attempt to have a reason to love herself. The whole community failed her in not showing enough empathy or care for her because they were all in some way, still attached to the ideals of beauty imposed by the mainstream culture.

Barbara Christian (1985) talks about how many of those people have been the result of migration from the South to Lorrain, Ohio (as it is the case, more explicitly with Pauline). They are, as a group, victims of the community that was there first and had economic power and an organized life structure, the white people. Christian emphasizes that in spite of trying to cope with that lack of acceptance by the city as a whole, the black community's lives are incoherent. They cannot make life work for them the way it should because of the status quo, the Dick and Jane expectations, the park that does not allow black people, the houses that differ so drastically from neighborhood to neighborhood, because of kids who perpetuate the predicaments of racism in school. Overall, they cannot better their lives because of a system that they seem to be unable to overcome by themselves alone.

\section{Concluding remarks}

The bluest eye has been widely studied regarding themes such as race, gender, beauty and love. We believe class is one of the important themes in this narrative and it is very attached to beauty, which is this novel is intensely expressed through space. Pecola has a difficulty, inherited from her family, in seeing beauty and positive values in herself because of her race, that is, the color of her skin, but also because of her class, that could be represented by the house where she lived with her family.

According to Kimberlé Crenshaw (2005), it is still a challenge, in identity politics, to discuss women and the matters concerning them, taking into consideration the various identity layers they bear, "race, class, and sexual orientation" (p. 533) being some of them. Crenshaw believes that "the experiences of women of color are frequently the product of intersecting patterns of racism and sexism (...) these experiences tend not to be represented within the discourses of either feminism or anti-racism" (idem). 
We can see that in the novel we observe here, race, class and gender are important intersecting factors about Pecola's identity. The violence she suffers, both physically and psychologically aim at these different dimensions of being and show how the coming of age for really darkskinned girls can be painful and unjust. The older women in Pecola's life and in her community also fail to help her cope with her loneliness, which proves that, even having experienced tough times growing up, women were not ready to act in favor of one of them who is still aging and changing.

The only people who truly welcome Pecola are the prostitutes who live on the upper part of her house. The one that is most affectionate to her is Maginot Line, a woman with a negative reputation and despised by other members of the community. Although Maginot Line's compassion encourages Pecola in a way, the prostitute was also one of the people who failed Pecola, because only loving her did nothing to change her condition. At the end of the narration, Claudia mentions her name when she says "[o]h, some of us 'loved' her. The Maginot Line" (MORRISON, 1994, p. 206), but in the same breath, she adds: "[t]here is no gift for the beloved. The lover alone possesses his gift of love. The loved one is shorn, neutralized, frozen in the glare of the lover's inward eye" (idem).

Angela Davis (2016) has observed that historically, women have had trouble aligning expectations and agendas in order to join forces in the fight against sexism and to achieve better work conditions. Because of such challenge, she denounces that the suffrage movement was racist in several situations, in spite of being widely composed of former abolitionists. Davis questions the openness and development of the North states during the nineteenth century, bringing this discussion to the table: if the progressive people were the ones acting politically to advance the North, how could they have racist actions in political and public forums and gatherings, and often times remain neutral about the questions of black women? This difficulty has existed because racism is a mentality deeply rooted in the United States and still present in circles and communities who profess progressive views. Much of the difficulty Pecola has in finding her place in the world has to do with the fact that she is victimized because of her belief in her lack of beauty - profoundly associated with the darkness of her skin. The feeling of inferiority is reflected in the relationships she has in her own house, her community, her school, and ultimately, in the city where she lives. These spaces are peopled by a majority blacks, but within 
their circle they encounter difficulties in identifying with each other and building a strong and supportive ethos.

Morrison succeeds in showcasing how much damage racism can cause in a person's life, especially if that person is such a frail member of society: a girl child. The glimpse we get, at how devastated Pecola's life was and how shattered her emotions became is shocking and causes an uneasiness that is necessary for us to take action against racism, still present in our days.

Before our houses can be lived and enjoyed by us, we need to recognize our bodies in all their complexity as our own house. By managing our own house, we can provide empathy to others, so that they will feel welcome in our house (in their relationship with us) and strong in their house (in their relationship with themselves). The responsibility we all share in the fact that racism still exists, has to do with a difficulty in understanding the importance of empathy, respect and love, all human values. We need all these attributes to keep not only our own house standing, on a personal level, but also to thrive and stand together in our communities.

\section{REFERENCES}

ALONGI, Samantha. Introspection and self-transformation in Toni Morrison's The bluest eye. Undergraduate Review. 5. Bridgewater: Bridgewater State University, 2009. Available at: http://vc.bridgew.edu/cgi/viewcontent.cgi? article=112 $8 \&$ context=undergrad_rev. Access on July, 7, 2018.

CHRISTIAN, Barbara. Black feminist criticism: Perspectives on black women writers. Oxford: Pergamon Press, 1985.

CRENSHAW, Kimberlé. Intersectionality and identity politics: learning from violence agaisnt women of color. IN: KOLMAR, Wendy K.; BARTKOWSKI, Frances (Ed.). Feminist theory: A reader. $2^{\text {a }}$. Ed. New York: McGraw-Hill Companies, 2005.

DAVIS, Angela. Mulheres, raça e classe. Tradução de Heci Regina Candiani. $1^{\text {a }}$. Ed. São Paulo: Boitempo, 2016.

FIGUEIREDO, Eurídice. Mulheres ao espelho: autobiografia, ficção, autoficção. Rio de Janeiro: EdUERJ, 2013.

GAMEIRO, Armindo da C. Escrever na primeira pessoa. IN: GAMEIRO, A da C. 
O espaço autobiográfico em José Craveirinha. Lisboa: Escolar Editora, 2012. p. $17-51$.

MORRISON, Toni. Behind the making of The Black Book. IN: DENARD, Carolyn. (Org.). What moves at the margin: selected nonfiction. Mississipi: The University Press of Mississipi, 2008.

. Playing in the dark: Whiteness and the literary imagination. $1^{\text {st }} \mathrm{Ed}$.

New York: Vintage Books, 1993.

. Rediscovering Black History. IN: DENARD, Carolyn. (Org.). What moves at the margin: selected nonfiction. Mississipi: The University Press of Mississipi, 2008.

. The bluest eye. $1^{\text {st }}$ Ed. New York: Plume/Penguin, 1994.

. Unspeakable things unspoken: The Afro-American presence in American Literature. The Tanner Lectures on Human Values. Michigan: The University of Michigan, 1988. p. 283 - 298. Available at: https://tannerlectures. utah.edu/_documents/a-to-z/m/morrison90.pdf . Access on May, 23 $3^{\text {rd }}, 2018$.

PARKER, Betty J. Complexity: Toni Morrison's women. IN: TAYLORGUTHRIE, Danille (Org.). Conversations with Toni Morrison. Mississipi: The University Press of Mississipi, 1994.

POWELL, Timothy B. Toni Morrison: the struggle to depict the black figure on the white page. Black American Literature Forum, Vol. 24, N. 4. 1990. p. 747 - 760. Available at: < https://repository.upenn.edu/rs_papers/11/>Access on May, $25^{\text {th }}, 2018$.

SEPTO, Robert. Intimate things in place: a conversation with Toni Morrison. IN: TAYLOR-GUTHRIE, Danille (Org.). Conversations with Toni Morrison. Mississipi: University Press of Mississipi, 1994.

WALTER, Roland. Out of in-betweeness: reading Toni Morrison's (double) writing. Transit circle - Revista brasileira de estudos americanos. V. 2. Rio de Janeiro: Contra Capa, 2003. p. 96 - 117.

Recebido em: 03/04/2019

Aceito em: 30/09/2019 